\title{
REVIEWS
}

The Nervous Child. By Hector Charles Cameron, M.A., M.D., F.R.C.P., Consulting Physician to the Children's Department, Guy's Hospital. London, Oxford Medical Publications. Fifth edition, 1946. Pp. 252. (Price 10s. 6d.)

As this has long been a classic, little more need be said than that the fifth edition differs only slightly from the last. The author has added particulars relating to umbilical colic, depth of sleep in enuresis, night terrors, and habitual vomiting of infancy. It must be rare indeed for a medical monograph to contain so much that is as true in 1947 as when it was written in 1919. Like Tristram Shandy, The Nervous Child should be read regularly; appetite will increase with eating.

The Purpose of the Family: A Guide to the Care of Children. By J. C. SPENCE, M.D., F.R.C.P., Nuffield Professor of Child Health in the University of Durham. The Convocation Lecture, 1946, of the National Children's Home, Highbury Park, London. Pp. 68. (Price 2s. 6d.)

As would be expected, this book is philosophical, stimulating, and occasionally provocative, and contains a wealth of common sense. It might well be called 'The Mother's Charter,' for seldom has her cause been more eloquently pleaded. It has become fashionable to blame the mother for having too few children, for relapsing into slutdom when she has too many children, for neglecting her children, for fussing her children, or for failing to breast-feed her children, and in general to visit the sins of the children on their female parent. There is something refreshingly sane and Victorian in Prof. Spence's view that the maternal instinct is something real and invaluable, built up through the experience of physical and emotional changes accompanying pregnancy, delivery, and lactation, and finally fulfilled through the handling of a family of children of different ages. He even goes so far as to uphold that the mother should be given the opportunity of nursing her sick child in hospital, and be allowed some of the credit for its recovery. That the future of child welfare should come to lie more and more in the hands of spinsters and civil servants, of whom an increasing number have never experienced membership of a large family, is a state of affairs which he rightly deplores. The author even has a kind word for the father, and assigns him a definite, if less important, rôle in the fostering of young children.

Although this lecture was delivered to a lay audience, it should be read by every paediatrician and child psychologist. The National Children's Home is to be congratulated on the choice of the first Convocation Lecturer, and on the decision to publish his lecture and make it available to a wider public.

The Embryology of Behaviour: The Beginnings of the Human Mind. By ArNold Gesell, M.D., Ph.D., Sc.D. In collaboration with CATHERINE S. Amatruda, M.D. London: Hamish Hamilton Medical Books. 1946. Pp. 775, 391 illustrations. (Price 21s.)

If the reader is prepared to accept the hypothesis that the premature baby can reasonably be described as a 'foetal infant,' he may feel that the title of this book is justified. If, on the other hand, he considers that the behaviour-development of the premature child is likely to be profoundly modified by spending the weeks preceding its expected birthday in the outside world instead of in the uterus, he is unlikely to accept Dr. Gesell's somewhat slipshod commentary on "the beginnings of the human mind.' In either case, this book contains some interesting photographic and other studies of premature babies of varying degrees of immaturity, is pleasingly produced, and should have a satisfactory sale amongst the senior author's large circle of fans.

\section{Pulmonary Tuberculosis: A Handbook for Students} and Practitioners. By R. Y. KeERS, M.D., F.R.F.P.S., and B. G. RIGDEN, M.R.C.S., L.R.C.P. With a Foreword by F. H. Young, O.B.E., M.D., F.R.C.P. Edinburgh, E. and S. Livingstone, Ltd. Second edition, 1946. Pp. 277. Profusely illustrated. (Price 17s. 6d.)

The paediatrician, who is likely to measure this book with his own yardstick, will be disappointed to find that neither ' infancy' nor ' childhood' appears in the index, and that there is no chapter devoted specifically to tuberculosis in early life. There is a brief discussion of the age-incidence of pulmonary infection, a reference to the use of B.C.G., and figures are given relating to various large-scale studies of positive tuberculin-reactors. The impression is gained, however, that the practitioner or student who obtained his information from this source would be left without any adequate idea of the importance of childhood tuberculosis as a cause of ill-health, and with little guidance as to how the individual child should be handled. Apart from these serious criticisms the book can be recommended as clearly written and containing a great deal of useful information in small compass; the fact that it has gone into a second edition a year after the publication of the first shows that it meets a real need. The production is excellent, and the many radiographs well reproduced. 